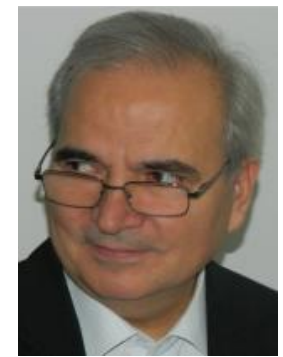

\title{
NEW DEVELOPMENTS IN PUBLISHING RELATED TO AUTHORSHIP
}

\author{
Doncho Donev
}

Institute of Social Medicine, Faculty of Medicine, "Ss Cyril and Methodius" University Skopje, R. Macedonia

Corespondence: Prof. Dr. Doncho Donev, Institute of Social Medicine, Faculty of Medicine, "Ss Cyril and Methodius" University, 50 Divizia 6, MKD Skopje, Republic of Macedonia. Phone: +389 (0)2 32985 80;

Mob: +389 702447 60; E-mail: dmdonev@gmail.com

\begin{abstract}
Aim: To present the inappropriate types of authorship and practice, and the most recent developments related to basic principles and criteria to a fair system for allocating authorship in scientific publications.

Methods: An analysis of relevant materials and documents, sources from the internet and published literature and personal experience and observations of the author.

Results: Working in multidisciplinary teams is a common feature of modern research processes. The most sensitive question is how to decide on who to acknowledge as author of a multi-authored publication. The pertinence of this question is growing with the increasing importance of individual VFIHQWMISXECDFDRQLEcords for professional status and career. However, discussions about authorship allocation might lead to serious conflicts and disputes among coworkers which could even endanger cooperation and successful completion of a research project. It seems that discussion and education about ethical standards and practical guidelines for fairly allocating authorship are insufficient and the question of ethical practices related to authorship in multi-authored publications remains generally unresolved.

Conclusion: It is necessary to work for raising awareness about the importance and need for education about principles of scientific communication and fair allocation of authorship, ethics of research and publication of results. The use of various forms of education in the scientific community, especially young researchers and students, in order to create an ethical environment, is one of the most effective ways to prevent the emergence of scientific and publication dishonesty and fraud, including pathology of authorship.
\end{abstract}

Key words: authorship, contributorship, scientific publishing, responsible conduct of research

\section{Introduction}

The long scientific hard work of several months or several years, and the research results achieved, need to be finalized with publication in a scientific journal in order to contribute to human knowledge and to be permanently available to the scientific community for critical reasoning. Publishing the results of scientific research in the form of a report (i.e. a scientific paper) is a crown and a final result of the research of each scientist. The phrase "publish or perish" reflects the pressure in the pro- fessional and academic environment for continuous publishing of new findings and results of professional, research and academic work for

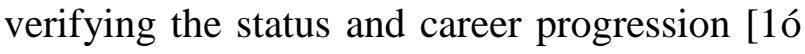
4]. The poor quality of many papers and journals, as well as increased average number of listed authors per article is often triggered by the tendency and practice for hyperproduction and misconduct in scientific publishing $[5,6]$.

To present and share the knowledge, skills and results of the professional scientific and academic work with the wider scientific com- 
munity it is necessary to write and publish papers in peer review scientific journals. But it is not easy and requires from scientists a sincere desire for knowledge, imagination and creativity, perseverance in the hard work and writing skills to prepare a scientific paper in accordance with internationally accepted principles and criteria in scientific communication $[4,7]$.

Science without publication is not science. Being a scientist requires publishing original research as an author of scientific publications which conveys responsibility for quality and integrity, from one side, and allocates professional benefit from credit for scientific advances. Biomedical authorship continues to have important academic, social, and financial implications and it is crucial in the career of a scientist $[8,9]$.

Authorship and contributorship is very important and sensitive, and not yet a completely resolved issue. Because the entire research and publication process relies on truthfulness and trust, unethical allocation of authorship that does not honor this connection between credit and accountability jeopardizes the scientific project as a whole. Authorship is about credit and responsibility for the quality and integrity of the work performed because academic life revolves around publication \pm being an author of as large a number of academic scientific papers as possible. Research evaluation is based on publication of the results in scientific journals. Grants depend on previous publications related to a particular problem or field and demands publication of the results in scientific journals. Publication brings professsional benefit in that it allocates credit for scientific advances, as well as fame for the authors in the professional and scientific community. Authorship in scientific publishing should accurately reflect individuals' contributions to the work and its reporting. The list of authors of a scientific paper should include all those and only those who meet applicable authorship criteria. If authorship should stay the main currency of science, it is necessary that the scientific community agree upon and establish rules for fair authorship allocation, to increase awareness and to educate, especially young researchers about those rules $[8,10 \pm 14]$.
The aim of this article is to present the inappropriate types of authorship and unethical practices and the most recent developments and challenges related to the basic principles and standards, and the best practice approaches and recommendations for deciding on authorship in scientific publishing.

\section{Inappropriate types of authorship}

Various types of pathology of authorship have been described in the published literature, including the three most common inappropriate types of authorship [11, 12, 15, 16]: guest authorship, honorary or gift authorship, and ghost authorship.

1. Guest authorship \pm based solely on an expectation that inclusion of a particular name will improve the chances that the study will be published or increase the perceived status of the publication. The "guest" author makes no discernible contributions to the study, so this person meets none of the criteria for authorship;

2. Honorary or gift authorship \pm based solely on a tenuous affiliation with a study i.e. "authorship" based on one's position as the head of a department in which the study took place (or to make a favour to a colleague in order to be obliged to return a gift authorship later on).

3. Ghost authorship. Ghost authors participate in the research, data analysis, and/or writing of a manuscript but are not named or disclosed in the author byline or acknowledgments. Examples of ghost authors include undisclosed contributors who are employees of pharmaceutical or device companies, medical writers, marketing and public relations writers, and junior staff writing for elected or appointed officials. Any person who makes a substantial contribution to a manuscript should be listed in the author byline, if appropriate, or in the acknowledgments, along with the individuals' institutional affiliations, if relevant.

Some other categories of authorship may be acceptable in certain circumstances:

- Anonymous Authorship. Because authorship should be transparent and requires public accountability, it is not generally appropriate to use pseudonyms or to publish scientific reports anonymously. In extremely rare cases, when the author can make a credible claim that attaching his or her name to the document 
could cause serious hardship (e.g., threat to personal safety or loss of employment for the author or an unacceptable risk that a patient could be identified, e.g. from a case study), a journal editor may decide to publish anonymous content.

- Group Authorship - may be appropriate when a group of researchers has collaborated on a project, such as a multicenter trial, a consensus document, or an expert panel. Because it can be inaccurate and impossible to list all collaborators (and byline space may preclude such a listing), authors need to think about how to communicate credit and responsibility for content.

The editors of JAMA have outlined 2 group authorship models [11, 12, 16, 17]:

\pm Authorship in which each person in the group meets authorship criteria, in which case the group is listed as the author, with the caveat that editors may require at least one coauthor to assume the role of content guarantor.

\pm Authorship in which a select subgroup of the whole is listed in the byline on behalf of the whole.

- Deceased or Incapacitated Authors If a coauthor dies or is incapacitated during the writing, submission, or peer-review process, coauthors should obtain disclosure and copyright documentation from a familial or legal proxy.

\section{Traditional ways of allocating authorship limits and common problems}

Traditional authorship practices assume that every author of a publication is involved in and knowledgeable about all aspects of the reported research. Such a straightforward approach toward determining authorship has become problematic in the complex projects with participation of various profiles of experts from different institutions. Co-authors of a multiauthored article are often not necessarily knowledgeable about all parts of the research they are involved in and therefore no longer able to take responsibility for each facet of the research in question. In this situation, it is difficult to assign appropriate credit and accountability operating with the traditional understanding of "author" [8, 18].

The core problem of the traditional system of authorship attribution is its non-transparency for readers and editors to know who among the authors was designing, carrying out, analyzing, and interpreting the reported research [8].

Authorship guidelines are not sufficient and need to be upgraded. They are not widely known and may even be ignored by many authors. Surveys suggest that knowledge of formal authorship criteria is highly variable and the majority of scientists are not familiar with existing criteria or do not consider formal criteria necessary [18 \pm 20$]$. Many empirical studies have demonstrated that there are very different attitudes toward granting authorship and that the majority of scientists give credit according to what "seems to be the right thing (to do), [21, 22]. Many authors of scientific publications do not fulfill the requirements for proper authorship. Godlee F, in 2009, reported results from two studies that more than $20 \%$ of medical articles have a "guest" author and journals are not doing enough to address the problem in order to reduce the number of "false" authors. In addition, about eight percent admitted that their article had a ghost author. According to those studies, ghost and guest authors were higher among research articles and case studies than in review articles and editorials [23]. More often the gift authorship is justified by friendly and collegial reasons and the fact that author and co-authors share common interest ("I'll add your name if you will add mine"). There are also cases of involuntary addition of an author, usually by junior researchers, due to the insistence of their mentor or superior, fearing a refusal might bring adverse conesquences for their status and career (Fig. 1), [5].

Disputes over authorship issues are a major concern in the day-to-day work of many scientists because existing guidelines may not be followed stringently or may be misinterpreted. Not many junior researchers have the courage to refuse polite requests from their seniors for inclusion as co-authors without or with negligible contribution to the work [12, 13, 24]. Many researchers reported that they have experienced not receiving appropriate credit for contributions they had made to published projects [22]. Ghost authorship is a problem because it prevents readers from knowing about some conflicts of interest since they do not know who the true authors were. 
The unfair attribution and vagueness in the byline still left unexamined because roles and expectations are often undefined and undis- closed. This may explain why disputes about authorship are increasingly common, so wasteful of time, and so poorly resolved [15, 20].

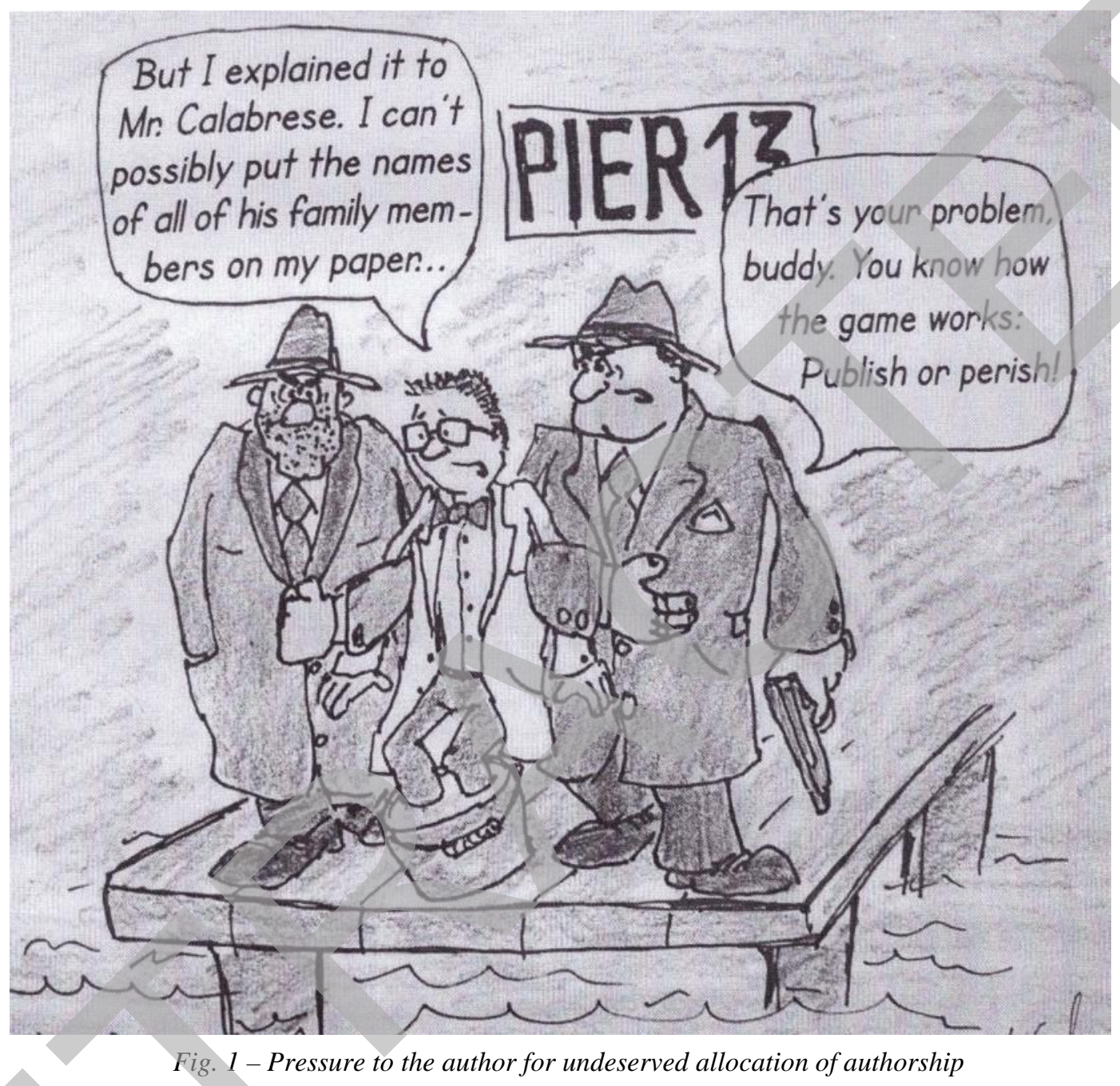

International criteria for authorship

A wide range of different institutions provide guidelines on ethical authorship, e.g., the International Committee of Medical Journal Editors (ICMJE), Council of Science Editors (CSE), Committee on Publication Ethics (COPE), World Association of Medical Editors (WAME), European Association of Science Editors (EASE), Office of Research Integrity (ORI), American Psychological Association etc. [11, 12, 15, 16, $25 \pm 28$ ]. Additionally, a number of journals and universities issue their own guidelines on authorship, e.g., Science's General Information for Authors, PLoS ONE Guidelines for Authors, Nature journals' Authorship Policy etc. [29 \pm 31 ].

The Mission of the ICMJE and many other international associations is to establish a stan- dardized approach for preparation of manuscripts and thereby help authors, editors, reviewers, readers and publishers of scholarly work. The ICMJE first published its Uniform Requirements (UR) for Manuscripts Submitted to Biomedical Journals in 1979 to establish a standardized approach for preparation of manuscripts and thereby help authors. Since then the Committee has made many changes to the document, including major revisions in 1997, 2003, 2010 and the last one in 2013 [11, 12]. The CSE in 2012 issued the White Paper on promoting integrity in scientific journal publications [15]. The EASE guidelines, from June 2013, also emphasized the ethical approach in determining the authorship [26].

According to the ICMJE-UR criteria for authorship from 2010 [11, 12, 32], an "author" 
is generally considered to be someone who has made substantive intellectual contributions to a published study, i.e. who significantly contri-

buted to all phases of research and writing of a manuscript for publishing (Box 1).

Box 1. The ICJME-UR basic criteria for authorship included in the 2010 and 2013 revision [11,12]
Authorship criteria for all authors to be listed:
• Authorship credit should be based on 1) substantial contributions to conception and design,
acquisition (collection) of data (study materials or patients), or analysis (statistical expertise) and
interpretation of data; 2) drafting the article or revising it critically for important intellectual content;
and 3) final approval of the version to be published. Authors should meet conditions 1,2, and 3;
4) In the 2013 revision the fourth criterion was added - author to agree to be accountable for
all aspects of the work in ensuring that questions related to the accuracy or integrity of any part of the
work are appropriately investigated and resolved.
• When submitting a manuscript authored by a group, the corresponding author should clearly
indicate the preferred citation and identify all individual authors as well as the group name. Journals
generally list other members of the group in the Acknowledgments. The NLM indexes the group name
and the names of individuals the group has identified as being directly responsible for the manuscript;
• Each author should have participated sufficiently in the work to take public responsibility for
appropriate portions of the content and integrity of the manuscript as a whole;
- All persons designated as authors should qualify for authorship, and all those should be
listed.
- One or more authors, referred to as "guarantors", be identified as the persons who take
responsibility for the integrity of the work as a whole, from inception to published article;
- Authorship of multicenter trials is attributed to a group. The group should jointly make
decisions about contributors/authors before submitting the manuscript for publication. The correspon-
ding author/guarantor should be prepared to explain the presence and order of these individuals.

The previous ICMJE-UR statement and recommendation that an author must take responsibility for at least one component of the work, should be able to identify who is responsible for each other component, and should ideally be confident in their co-authors' ability and integrity was changed in the 2013 revision with broadening accountability to all authors for all aspects of the work and publication $[11,12]$.

\section{Why did ICMJE include the fourth criterion?}

Individual authors have often responded to inquiries regarding scientific misconduct related to some aspect of the study or paper by denying responsibility. In such cases their common answer was: "I didn't participate in that part of the study (or in writing that part of the paper), ask someone else". So, the fourth criterion for authorship was necessary so that each author of a paper is obliged to understand the full scope of the work, to know which coauthors are responsible for specific contributions, and have confidence in their co-authors' ability and integrity. When questions arise re- garding any aspect of a study or paper, the onus is on all authors to investigate and ensure resolution of the issue $[11,12]$.

\section{Broadened responsibility to all authors of the paper}

Individuals listed as authors should meet all four ICMJE criteria for authorship and to review and approve the manuscript before submitting for publication. By accepting authorship of a paper, an author should take public responsibility for the work and should have full confidence in the accuracy and integrity of the work of other group authors. All authors are expected as individuals to complete an authorship statement and conflict-of-interest disclosure forms upon the journal editor's request. An author should accept that any problem related to that paper is his/her problem. Often most authors cannot participate directly in every aspect of the work, but ICMJE holds that each author remains accountable for the work as a whole by knowing who did what, and by helping to resolve questions or concerns if they arise [11, $12,15]$. 
This new criterion better balances credit with responsibility, and establishes the expectation that editors may engage all authors in helping to determine the integrity of the work. Policies and procedures for disclosure of research contribution in journal articles would help to reduce irresponsible authorship $[11,12,21]$.

\section{Who decides about the authorship of a paper?}

According to the ICMJE, "The authorship criteria are not intended for use as a means to disqualify colleagues from authorship who otherwise meet authorship criteria by denying them the opportunity to meet criterion \#s 2 or 3 . Therefore all individuals who meet the first criterion should have the opportunity to participate in the review, drafting, and final approval of the manuscript". As always the decision about who should be an author on a given article is the responsibility of the people who did the work (the researchers) and not the people who publish the work (publishers or editors of the journal to which the work has been submitted). This means that collaborating partners should come to agreement and determine, possibly at the beginning of the research work and later as needed, on standards for authorship and which individuals have contributed sufficiently to the work to warrant identification as an author. If potential authors cannot reach agreement about who does and who doesn't qualify for authorship, then the institution(s) where the work was performed, and not the journal editor, should be asked to investigate and arbitrate authorship conflicts [12, 15, 32, 33].

The order of authors in the byline should be a collective and transparent decision of researchers or the study group depending on each researcher's relative portion and significance of contribution to the project and publication. The agreed number and order of the authors in the byline might be changed during the research work or writing the manuscript, or even (very rarely) after submission for publishing (e.g. if a paper changes substantially in response to reviewer comments). Journal editors should ask for an explanation and signed statement of agreement for the requested change from all listed authors, as well as from the author to be added or removed [16]. One of the authors should be the "guarantor" of the publication, a person who made added efforts, and will take public responsibility, to ensure the integrity of the work as a whole, from "inception to published article" [12, 15, 27]. It is usually, but not necessarily, the first author who might be also the corresponding author for communication with the journal during the manuscript submission, peer review and publication process for providing necessary information to the journal editors related to the research process and manuscript, in a timely way as well as to be available after publication to respond to critiques of the work and provide additional information, if necessary $[8,12,28]$.

Heads of departments, superiors and senior colleagues, members of the scientific boards/ committees and even mentors, should be included as co-authors only if they contributed substantially to writing the manuscript, and not just automatically in accordance with their position and hierarchy of the institutions, nepotism, loyalty or gratitude. Among the most common authorship misuse refers to the so-called undeserved or gift authorship, i.e. including in the byline persons who didn't participate in the work [5, 6, 33]. Wager E, 2009, argues that "if scientists or clinicians are prepared to lie about who was involved with a research project why should we believe their findings?" [34].

Rarely, in case of almost equal contribution to the research and preparation of manuscript of two or more authors, they might agree with names of authors being listed in alphabetical order or by tossing a coin.

\section{ICMJE criteria for contributorship/collaborators listed in acknowledgements}

It is not appropriate for a person who was solely responsible for the acquisition of funding, collection of data, general administrative support and writing assistance, technical or language editing or general supervision of the research group, to be listed as an author of a scientific publication. Various types of contributions of collaborators and supporters, who contributed to the work but whose contributions were not of sufficient magnitude, should be identified by name (with their agreement) and properly credited in the acknowledgements section of the paper [8, $12,15,33]$. The ICMJE criteria for contributorship are summarized in Box 2 . 
Box 2. The ICJME criteria for contributorship/ collaborators listed in acknowledgements [12]

Contributorship criteria for contributors to be listed in an acknowledgments section:

- Acquisition of funding, collection of data, or general supervision of the research group alone;

- A person who provided purely technical help, administrative/ technical/ logistical support and writing assistance, or a department chairperson who provided only general support;

- Financial and material support should also be acknowledged;

- Groups of persons who have contributed materially to the paper but whose contributions do not justify authorship may be listed under such headings as "clinical investigators" or "participating investigators", and their function or contribution should be described-for example, "served as scientific advisors", "critically reviewed the study proposal", "collected data", or "provided and cared for study patients", and these persons must give written permission (at least oral) to be acknowledged.

Potential beneficiaries of a transparent and fair system of allocating authorship

Who is benefiting the most from a transparent and fair system of allocating authorship is an open question. Some authors suggested that journal editors, and in particular readers of scientific articles will mostly benefit from the disclosure of individual contributions to scientific publications [8]. On the other hand, there is no doubt that clear principles and journal policies may help to reduce authorship disputes and therefore authors would benefit the most. Scientists reported that the contributorship approach is a convincing and promising way to "arrive at an equitable assignment of authorship". It means that journal editors should demand from all authors of a manuscript submitted for publication to sign an "Authorship statement" of his/her contribution to the work which will be published at the end of the article under the heading "Author contributions" [5, 8, $15,35,36]$.

Many empirical studies clearly indicate that transparent standards of authorship significantly improve the validity of authorship [21]. Therefore, the systematic education of young scientists and students, but also of senior scientists, with respect to ethical publication standards and integrity is crucially important [4, 37, 38]. Furthermore, senior researchers and especially supervisors and mentors should actively promote ethical principles and criteria for authorship allocation so that young researchers are empowered to react appropriately when being confronted with unacceptable behavior displayyed by colleagues [39]. Moreover, active involvement from research institutions, universities, editors, and publishers in making ethical publication standards better known is recommended
[9]. Increased awareness of the problem may lead to reduce deviations from appropriate conduct. Journal editors should promote research and publishing integrity and develop and implement contributorship policy $[38,40]$.

\section{Conclusion}

The debate about authorship ethics in the field of biomedicine is still continuing.

Researchers in the field should follow the best practice principles and available resources when deciding on how to fairly assign credit and responsibility in scientific publishing. All persons designated as authors should qualify for authorship by sufficient meaningful participation in the work and to take public responsibility for the entire content of the paper, and all those who qualify for authorship should be listed as authors in the publication.

Honesty in science is the foundation of its existence. Ethics of science is difficult to describe and to define. Everything in the scientific work should be done honestly and objectively, to suppress individual vanity and desire for undeserved personal gain and selfish display, to be honest in conclusions, fair and equitable to associates, to be consistent in accuracy and never to change or fabricate the data, not to attain intellectual property from any other, no matter how it may seem irrelevant or invisible. Scientists are both entrusted and obliged to follow ethical standards when proposing, performing, reviewing, and reporting research or when educating and mentoring young researchers. Various forms of education of the scientific community on research and publishing integrity, and basic principles and criteria for authorship related decisions, are necessary in order to create ethical environments. 
Editors are strongly encouraged to develop and implement a contributorship policy, as well as a policy on identifying who is responsible for the integrity of the work as a whole. Even it is still an unresolved question of the quantity and quality of contribution that qualify for authorship, such policies would favor deserving authorships and transparency of data on the sources of funding research as essential preconditions for strengthening ethical approach and integrity in research and publishing.

\section{REFERENCES}

1. Neill US. Publish or perish, but at what cost? J Clin Invest. 2008; 118: 2368.

2. Bilić-Zulle L. Research integrity - a cornerstone of existence and development of science [In Croatian]. Biochemia Medica. 2007; 17: 143-50.

3. Donev D. Scientific and Publication Ethics and Misconduct. [In Macedonian]. Vox Medici. Dec 2012; 77: 235-40. Available at:

http://www.lkm.org.mk/VoxMedici/77.pdf Accessed: June 30, 2014.

4. Donev D. Principles and ethics in scientific communication in biomedicine. Acta Informatica Medica. 2013; 21 (4): 228-33. Available at:

http://www.scopemed.org/?jid=6 Accessed: June 30, 2014.

5. Dobric S. Authorship misusing in scientific publiccations. Vojnosanitetski pregled. 2012; 69(12): 1028-30.

6. Ignjatovic M. The authors and "authors". Vojnosanitetski pregled. 2006; 63(3): 239-46.

7. Hwang K. How to Write a Scientific Paper: Three Tips to Remember. Arch Plast Surg. 2012 January; 39(1): 77. Available at:

http://europepmc.org/articles/PMC3385294/pdf/aps39-77A.pdf Accessed: June 30, 2014.

8. Eggert LD. Best Practices for Allocating Appropriate Credit and Responsibility to Authors of MultiAuthored Articles. Front Psychol. 2011; 2: 196. Available at:

http://www.ncbi.nlm.nih.gov/pmc/articles/PMC3164 109/ Accessed: Jun 24, 2014.

9. Horner J, Minifie F. D. Research ethics III: publiccation practices and authorship, conflicts of interest, and research misconduct. J. Speech Lang. Hear. Res. 2011; 54: S346-S362.

10. Wager E, Kleinert S. Why do we need international standards on responsible research publication for authors and editors? Journal of Global Health. 2013; 3(2): 1-7. Available at:

http://jogh.org/documents/forthcoming/V1\%20Wage r\%20FINAL.pdf Accessed: Sept 12, 2014.

11. International Committee of Medical Journal Editors (2011). Uniform Requirements for Manuscripts Submitted to Biomedical Journals: Ethical Considerations in the Conduct and Reporting of Research: Authorship and Contributorship. Available at:

http://www.icmje.org/ethical_1 author.html Accessed: June 30, 2013.

12. ICMJE. Recommendations for the Conduct, Reporting, Editing, and Publication of Scholarly Work in Medical Journals* - Updated December 2013. Available at:

http://www.icmje.org/icmje-recommendations.pdf Accessed: Apr 7, 2014.

13. Claxton LD. Scientific authorship. Part 1. A window into scientific fraud? Mutat. Res. 2005 Jan; 589(1): 17-30.

14 Steneck N, Mayer T. Singapore Statement on Research Integrity. Available at:

http://www.singaporestatement.org/ Accessed: Apr 7, 2014.

15. Council of Science Editors. CSEs White paper on Promoting Integrity in Scientific Journal Publications. 2012 Update. Available at:

http://www.councilscienceeditors.org/resourcelibrary/editorial-policies/white-paper-on-publicationethics/ Accessed: Aug 14, 2014.

16. Committee on Publication Ethics. Promoting integrity in research publication. Available at:

http://publicationethics.org/ Accessed: Jul 20, 2014.

17. American Medical Association. Manual of Style. Available at: http://www.amamanualofstyle.com/ Accessed: Jul 20, 2014.

18. Smith E, Smith E, William-Jones B. Authorship and responsibility in health sciences research: a review of procedures for fairly allocating authorship in multiauthor studies. Sci Eng Ethics. 2012; 18(2): 199-212.

19. Bhopal R, Rankin J, McColl E, et al. The vexed question of authorship: views of researchers in a British medical faculty. BMJ. 1997; 314: 1009-12. Available at: http://www.bmj.com/content/314/7086/1009?ijkey=b d3d533c7224960ab169a64e4ecdf00808154574\&keyt ype2=tf_ipsecsha Accessed: Sept 20, 2014

20. Kakkar N. Authorship trends in the Indian Journal of Pathology and Microbiology: going the global way? - Correspondence. J Clin Pathol. 2004; 57: 670. Available at: http://jcp.bmj.com/content/57/6/670.1.full Accessed: Apr 20, 2014

21. Marusic A, Bates T, Anic A, Marusic M. How the structure of contribution disclosure statements affects validity of authorship: a randomized study in a general medical journal. Curr. Med. Res. Opin. 2006 Jun; 22(6): 1035-44.

22. Seeman JI, House MC. Influences on authorship issues: an evaluation of giving credit. Account. Res. 2010; 17(3): 146-69.

23. Godlee F. More than $20 \%$ of medical articles have a "guest" author. British Medical Journal (Overseas \& Retired Doctors Edition). 2009; 339(7722): p652. Available at:

http://connection.ebscohost.com/c/articles/44376071/ more-than-20-medical-articles-have-a-guest-author Accessed: Sept 12, 2014.

24. National Institutes of Health (NIH). Authorship and disputes. Available at: 
http://search.nih.gov/search?utf8=\%E2\%9C\%93\&aff iliate $=$ nih \&query $=$ Authorship + and + disputes \&commi t. $x=31 \&$ commit. $y=6$ Accessed: Jul 18, 2014.

25. WAME. The Principles of Transparency and Best Practice in Scholarly Publishing. Available at: http://www.wame.org/News/Details/2 Accessed: Jul 18, 2014.

26. European Association of Science Editors. EASE Guidelines for authors and translators of scientific articles to be published in English. June 2013. Available at: http://www.ease.org.uk/sites/default/files/ease_guidel ines-june2013-english.pdf Accessed: Apr 8, 2014.

27. The Office of Research Integrity. Annual Report 2010. Available at:

http://ori.hhs.gov/images/ddblock/ori_annual_report_ 2010.pdf Accessed: Jul 18, 2014.

28. American Psychological Association (2011). Publication Practices and Responsible Authorship. Available at:

http://www.apa.org/research/responsible/publication/ index.aspx Accessed: Aug 26, 2014.

29. Science. General Information for Authors. Available at: http://www.sciencemag.org/site/feature/contribinfo/p rep/gen_info.xhtml Accessed: Sept 15, 2014.

30. PLoS ONE. Guidelines for Authors. Available at: http://www.plosone.org/static/guidelines Accessed: Sept $15,2014$.

31. Nature. Authorship Policies. Available at: http://www.nature.com/nature/journal/v458/n7242/fu 11/4581078a.html Accessed: Sept 15, 2014.

32. Masic I, Kujundzic E. Science editing of academic periodicals in biomedical and social sciences. Avicena. Sarajevo, 2013: 278.

33. Montreal 4th World Conference on Research Integrity. Montreal Statement on Research Integrity. Available at:

http://www.cehd.umn.edu/olpd/MontrealStatement.pdf Accessed: Sept 15, 2014.

34. Wager E. Recognition, reward and responsibility: why the authorship of scientific papers matters. Maturitas. 2009 Feb 20; 62(2): 109-12.

35. Katavić V. Responsible conduct of research. In: Marušić M (ed.) Principles of research in medicine. Zagreb: Medicinska naklada. 2008: 234-45.

36. Albert T, Wager E. How to Handle Authorship Disputes: A Guide For New Researchers. The COPE Report 2003 (July 1). Available at:

http://www.publicationethics.org/resources/guidelines

37. Heitman E, Litewka S. International perspectives on plagiarism and considerations for teaching international trainees. Urol. Oncol. 2011; 29(1): 104-8.

38. Scheetz M. The Teaching Scholars Program: a proposed approach for promoting research integrity. In: Carmi A, Ferris L, Nachshon D, eds. Medicine and law - Theme issue on scientific misconduct. World Association for Medical Law. Medicine and Law. 2007; 26(3): 599-614.

39. Wagena E.J. The scandal of unfair behaviour of senior faculty. J. Med. Ethics. 2005 May; 31(5): 308.
40. Marusic A, Katavic V, Marusic M. Role of editors and journals in detecting and preventing scientific misconduct: strengths, weaknesses, opportunities, and threats. In: Carmi A, Ferris L, Nachshon D, eds. Medicine and law - Theme issue on scientific misconduct. World Association for Medical Law. Medicine and Law. 2007; 26(3): 545-66.

\section{Резиме}

TE

\section{ончо онев}

Институт за социјална медицина, Медицински факултет, Универзитет „Св. Кирил и Методиј“ Скопје, Р. Македонија

ел: Да се прикажат несоодветните видови авторство и практика, како и најновите случувања поврзани со основните принципи и критериуми за фер систем за распределба на авторството во научните публикации.

$e \bar{u} о д и:$ Анализа на релевантни материјали и документи, извори од интернет и објавена литература и лично искуство и опсервации на авторот.

езулй $\bar{u} u$ : Заедничка карактеристика на современите истражувачки процеси е работата во мултидисциплинарни тимови. Најчувствителното прашање е како да се одлучи за тоа кои лица да бидат вклучени како автори на мултиавторски труд. Актуелноста на ова прашање се зголемува со зголемувањето на важноста на бројот на објавени научни трудови на одделни научници за нивниот професионален статус и кариера. Од друга страна, дискусиите за распределба на авторството може да доведат до сериозни конфликти и спорови меѓу соработниците дека дури и може да ја загрозат соработката и успешното завршување на целиот истражувачки проект. Се чини дека дискусијата и едукацијата за етичките стандарди и практичните насоки за праведна распределба на авторството се недоволни и прашањето на етички практики поврзани со авторството во мултиавторски публикации останува генерално нерешено.

клучок: Потребно е да се работи за подигање на свеста за важноста и потребата од образование за принципите на научна комуникација и фер распределба на авторството, етика 
во истражувањето и објавувањето на резултатите. Употребата на различни форми на едукација на научната заедница, особено на младите истражувачи и студентите, со цел да се создаде етичка средина, е еден од најефикасните начини да се спречи појавата на научна и објавувачка нечесност и измами, вклучувајќи и патологија на авторството.

лучни зборови: авторство, помош и поддршка, научно издаваштво, одговорно спроведување на истражување. 